\title{
Agata Skurzewska
}

Uniwersytet Jagielloński

Instytut Filologii Wschodniosłowiańskiej

ORCID: 0000-0002-1561-9944

\section{Матеріялы до руского словаря - rękopiśmienny dziewiętnastowieczny słownik ukraińsko-polski Josyfa Skomorowskiego}

\begin{abstract}
Abstrakt: Ukraińsko-polski rękopiśmienny słownik Josyfa Skomorowskiego Матеріяль до руского словаря liczy pięć tomów i 1732 strony. Prawdopodobnie został ukończony w 1849 roku. Ukraiński rejestr słownika obejmuje 27000 haseł. Materiał ukraiński słownika obfituje w polonizmy, zarówno fonetyczne, jak i leksykalne, a także w leksykę wykazującą cechy dialektalne. Nie wszystkie hasła ukraińskie zostały przetłumaczone. Najwięcej braków widocznych jest w tomie IV. Część materiału ukraińskiego została podana w dwóch wariantach ortograficznych, ponieważ Skomorowski trzymał się początkowo zasad ortografii fonetycznej, później zaś zweryfikował ukraińską część zgodnie z ortografią etymologiczną. Słownik nie jest wolny od błędów w tłumaczeniu, zawiera też leksykę ukraińską, której istnienia nie udało się potwierdzić w innych źródłach.
\end{abstract}

Słow a klucze: XIX-wieczna leksykografia ukraińska; Skomorowski; południowo-zachodnie dialekty języka ukraińskiego; leksyka dialektalna 
Rękopiśmienny słownik ukraińsko-polski Josyfa Skomorowskiego Mameріяль до руского словаря, собранӥи Іосифомъ Скоморовскимъ, Парохомь въ Березовици великой liczy pięć tomów i 1732 strony¹.

Autor słownika, Josyf Skomorowski (1815-1891), greckokatolicki duchowny, językoznawca, tłumacz, aktywny uczestnik kulturalnego i religijnego ukraińskiego odrodzenia w Galicji, od 1838 roku był parochem w Berezowicy Wielkiej w obwodzie tarnopolskim (ODA 2020; Галас 1995: 61). Współpracował z „Ruską Trójcą”2.

W I tomie słownika autor umieścił informację: „Тіи матеріялы до руского Словаря жертвую до книгохранилища руского народного дому въ Лвовь. - Березовиця велика въ Грудню 1862. Іосифъ Скоморовскій”. Wyraził też nadzieję, że zebrany przez niego materiał będzie wykorzystany przy ułożeniu słownika, który miał być przygotowany pod opieką Juliana Ławrowskiego (Литературни въсти 1862), czyli późniejszego niemiecko-ukraińskiego słownika Omelana Partyckiego (Нгъмецко руский словаръ черезъ О. Партицєкого, Львоิвъ 1867). O. Partycki we wstępie do niego wymienił manuskrypt J. Skomorowskiego wśród źródeł ukraińskiego rejestru słownika (Skurzewska 1999: 146). Z rękopisu J. Skomorowskiego korzystał też prawdopodobnie Jakiw Hołowacki przy opracowywaniu materiałów do ułożonego przez siebie słownika: Материаль для словаря малорусского наречия, собранные в Галицини и в северно-восточной Венгрии (Галас 1995: 62). Sam J. Hołowacki wspomina o słowniku J. Skomorowskiego w liście do Osypa Bodianskiego z 9 kwietnia 1849 roku: „Йосиф Скоморовський зібрав словар малоруського язика, до 30000 слів, із фразеологією і толкуванням польським, і гадає пренумерату оголосити на те діло, бо ні сам, ні Матиця не мають такого фонду, щоб так обширне діло випечатати” (Стеблій 1989). Z korespondencji możemy zatem wniosko-

1 Słownik przechowywany jest we Lwowskiej Narodowej Naukowej Bibliotece Ukrainy im. Wasyla Stefanyka pod sygnaturą ACП 305.

2 Ruska Trójca (Руська трійия) to nazwa utworzonego w latach 30. XIX wieku w Galicji ugrupowania społeczno-kulturalnego, założycielami którego byli: Markjan Szaszkewycz, Iwan Wahylewycz i Jakiw Hołowacki. Jego celem było, przede wszystkim, podniesienie rangi języka ukraińskiego (określanego wówczas mianem ruskiego - руська мова) oraz oczyszczenie go z wpływów mowy cerkiewnosłowiańskiej i języków obcych (głównie polskiego i rosyjskiego). Jednym z największych osiągnięć tego ruchu było wydanie w 1837 roku w Budapeszcie almanachu Русалка Днъпровая, zob. Украйнська мова. Енииклопедія (2000: 58, 95, 734). 
wać o roku powstania słownika, czyli zakończeniu prac nad nim - przed lub w 1849 roku.

Ukraiński rejestr słownika liczy 27000 haseł (Галас 1995: 62), przy czym część materiału ukraińskiego podana została w dwóch wariantach ortograficznych, ponieważ J. Skomorowski początkowo podawał leksykę ukraińską zgodnie z zasadami ortografii fonetycznej, później zaś zweryfikował jej zapis zgodnie z wymogami ortografii etymologicznej, i stąd zapisy, np. нic но̂с, ніч - ноิч, вісь leksykę od litery $a$ do $\tau$, tom II - 137 i litery od $\partial$ do $\breve{u}$, tom III - 180 i litery od $\kappa$ do $o$, tom IV -220 i leksykę na $n$, tom V -183 i litery od $p$ do $w$. Większość wyrazów ma zaznaczony akcent. Nie wszystkie hasła ukraińskie zostały przetłumaczone. Najwięcej braków widocznych jest w tomie IV (poczynając od litery $n$, coraz więcej leksemów pozbawionych jest przykładów w języku polskim). Przy nazwach roślin bądź zwierząt autor uzupełnia komentarz poprzez zapisanie odpowiednika niemieckiego lub łacińskiego, np. Papiz (рӧг) 'raróg (der Blaufuss - птах)'3; Бабка 'babka (die Grossmutter)', 'babka, ziele (alisma plantago)'; Каня 'kania (Hühnergeier)'; Жук ‘żuk (der Mistkafer)'. Niekiedy opisowo uściśla znaczenie, podaje konstrukcje wyrazowe lub związki frazeologiczne, ilustruje przykłady przysłowiami bądź fragmentami piosenek, np. Амънь 'koniec, zguba': аж там јему буде амгнь; Апостол 'Apostoł, Księga zawierająca dzieje i listy apostolskie, lekcya, która się podczas mszy czyta z tejże Księgi'; Бајбарз, Бајбарзо, Бајдуже 'bаjbardzo, bynajmniej, wcale nie, mniejsza o to', н.п. умерл батько - бајбарзо, вмерла мати - бајдуже, вмерла моја миленькаја - тожто менгь жяль дуже (спьванка). W nawiasie autor umieszcza też synonim bądź wariant fonetyczny wyrazu ukraińskiego, np. Авгусm 'miesiąc Sierpień', (Серпень); Альмужна 'almużna', (Даток); Анна (Ганна) 'Anna'; Веселғишиј (także Веселтъщиј) adj. com. od Веселиј. Niekiedy tłumaczenie jest bardzo ogólne, np. Крвавник 'jakaś roślina'. Wyrazem hasłowym może być forma 1 os. $1 \mathrm{p}$. czasownika, np. Мелю 'mielę', (Молоти); Зітну 'zetnę'.

Przy materiale ukraińskim autor podaje kwalifikatory wskazujące na: rodzaj gramatyczny rzeczowników: $m ., f$., $n$; część mowy (ale dotyczy to tylko przymiotników, przysłówków, liczebników i spójników): adj., adv.,

3 Wszystkie przykłady ze słownika podaję w oryginalnym zapisie, który często odbiega od współczesnej normy. 
num., conj.; rzeczowniki pluralia tantum oznacza poprzez kwalifilkator pl. (Вечерниць pl. 'wieczorki'); niekiedy umieszcza końcówkę lub pełną formę dopełniacza lp. rzeczowników: Брiд (gen. Бродy) 'bród', Доготь (gen. Дігтю) 'diegiedź', Корч (gen. Корчу) 'kurcz'.

Josyf Skomorowski stosuje kwalifikatory odnoszące się do pochodzenia lub zasięgu terytorialnego materiału ukraińskiego: $u k r$. , cerk., po dziecięce$m u$, gór. Kwalifikator $u k r$. umieszcza autor prawdopodobnie przy leksyce odbieranej jako właściwej terenom Ukrainy Wschodniej, np. Бајрак 'dolina'; cerk. - to cerkiewizmy, np. Агнеи 'hostia'; Ад 'piekło'; Беззаконїе 'nieprawość'; po dziecięcemu - wyrazy charakteryzujące język dzieci: Базя 'owca' lub 'jagnię'; gór. - to leksyka gwarowa obecna na obszarach górskich dialektów południowo-zachodnich, czyli cechująca gwary huculskie, bojkowskie, pokucko-bukowińskie czy zakarpackie, np. Веремънь 'piękna pogoda' - w dialektach odnotowano zbliżoną formę veremij 'pogoda, ładna pogoda' (na Huculszczyźnie), 'piękna, słoneczna pogoda' (huculskie wsie na Zakarpaciu), 'deszcz, niepogoda, słota' (na Bojkowszczyźnie) (AGB V, m. 278); Въвкати 'krzyczeć, hałasować (w lesie)' - leksem poświadczony w gwarach huculskich (Janów 2001: 260) oraz bojkowskich (Онишкевич I, 115); Кошъль 'kosz' - wyraz zanotowany w gwarach bojkowskich 'кошик з лози для картоплі' (Онишкевич I, 383); Макотер 'макітра' - leksem obecny w gwarach bojkowskich 'ts.' (ЕСУМ III, 365); Шимбалок 'listwa' - w gwarach бojkowskich: шимбарок 'місце під полицею, де несуться кури' (Онишкевич II, 382).

Leksyka ukraińskiego rejestru słownika, także ta nieoznaczona kwalifikatorami, wykazuje liczne cechy zarówno fonetyczne, jak i morfologiczne, właściwe przede wszystkim południowo-zachodnim dialektom języka ukraińskiego ${ }^{4}$ :

- realizacja połączenia spółgłoski płynnej [r] z jerami w pozycji słabej jako [yr]: Киртиия 'kret' (zjawisko charakterystyczne dla dialektów południowo-zachodnich (Бевзенко 1980: 79);

- zachowanie nieakcentowanego [o] przed sylabą z akcentowanym [a]: Богат, Богатиј 'bogaty'; Колачь 'kołacz' (cecha dialektów połu-

4 Podaję wybrane przykłady form dialektalnych. Szczegółowy opis właściwości gwarowych obecnych w leksyce słownika J. Skomorowskiego przedstawiła Iryna Sus, zob. Cyc 2011. 
dniowo-zachodnich oraz gwar zachodniopoleskich (Матвіяс 2004: 16; Жовтобрюх 1979: 289);

- w rzeczowniku вогонь pojawia się wstawna samogłoska [e]: Огень 'ogień, gorączka' (zjawisko typowe dla dialektów południowo-zachodnich (Бевзенко 1980: 58);

- brak wzdłużenia spółgłoski tematycznej w rzeczownikach rodzaju nijakiego II deklinacji typu зілля, житта: Галузье (colect.) 'gałęzie' (cecha dialektów południowo-zachodnich (Бевзенко 1980: 84);

- wtórna epenteza [1] po spółgłoskach wargowych: Деревяниј (Дервляний) ‘drewniany' (zjawisko właściwe dialektom południowo-zachodnim, obecne szczególnie na Podolu, nad Dniestrem oraz na Zakarpaciu (Бевзенко 1980: 66; Шевельов 2002: 643);

- zastąpienie połączenia spółgłosek [xv] przez [f]: Фicm (Фӧcm) 'ogón' (cecha dialektów południowo-zachodnich, szczególnie gwary huculskiej (Бевзенко 1980: 64-65; Кобилянський 1960: 137);

- zachowanie spółgłoski [h] w przysłówku гдe: Де, Где 'gdzie' (cecha obecna zarówno w dialektach południowo-zachodnich, jak i południowo-wschodnich oraz poleskich (Бевзенко 1978: 361);

- obecność spółgłoski protetycznej [h] przed [a]: Арак (Гарак) 'arak' (zjawisko obejmuje gwary od wschodniego Polesia do strefy stepowej i od Sanu do Dońca (nieobecne w gwarach łemkowskich, natomiast z ograniczonym charakterem $w$ gwarach bojkowskich, huculskich i zakarpackich (Шевельов 2002: 579);

- brak spółgłoski protetycznej [h] przed [o] lub też zastąpienie protetycznego [h] spółgłoską [v]: Bopђx, Opђx (formy z protetyczną spółgłoską [v] poświadczone są w gwarach bojkowskich (Онишкевич II, 24) oraz punktowo w rejonie rachiwskim w obrębie gwar huculskich (Дзендзелівський 2000: 73); brak spółgłoski protetycznej cechuje, z jednej strony, gwary środkowo- $i$ wschodniopoleskie, $z$ drugiej - karpackie (większość łemkowskich, a także bojkowskie, huculskie i zakarpackie (Шевельов 2002: 573);

- obecność spółgłoski protetycznej [v] przed [o]: Вотеus (g. Вiтu̧я) 'ojciec' (Отець) (zjawisko obejmuje gwary naddniestrzańskie i nadsańskie, Podlasie, zachodnią część Podola, częściowo gwary bukowińsko-pokuckie, wschodniobojkowskie i wschodniołemkowskie, lo- 
kalnie obecne jest też na zachodnim Polesiu i środkowym Zakarpaciu (Бевзенко 1980: 83; Шевельов 2002: 572);

- zjawisko metatezy: Вогорити, Говорити (czasownik odnotowany w gwarach halicko-bukowińskich (Бевзенко 1980: 84), na wschodnim Polesiu oraz Chmielnicczyźnie (Шевельов 2002: 949);

- mianownik lp. rzeczownika миша ma postać миш: Миш 'mysz' (forma, będąca kontynuacją postaci prasłowiańskiej *myšь, znana jest gwarom zakarpackim, łemkowskim oraz gwarze Batiuków (Бевзенко 1960: 52);

- formy enklityczne zaimków osobowych: Тя 'cię’ zamiast Тебe (cecha właściwa gwarom halicko-bukowińskim, karpackim i części wołyńsko-podolskich (Бевзенко 1980: 119);

- formy liczebników: Оденајиять ‘jedenaście’ (typowe dla dialektów południowo-zachodnich, zwłaszcza naddniestrzańskiego (Бевзенко 1980: 117);

- bezokolicznik czasowników o dawnym temacie na spółgłoski * $[\mathrm{g}]$, *[k] zakończony na - čy: Допечи 'dopiec'; Зречи ся 'zrzec się'; Лягчи 'ledz, położyć się'; Набъжчи (cecha dialektów południowo-zachodnich: gwary południowowołyńskie, halicko-bukowińskie i karpackie (Бевзенко 1960: 127; Кобилянський 1960: 184).

Ukraiński materiał słownika obfituje w polonizmy, zarówno fonetyczne, jak i leksykalne, np. Бадати 'badać', Бадачь 'badacz', Безчельниј 'bezczelny', Глодовиј 'głodowy', Гіль 'gil', Дозберати 'dozbierać', Јабко, ob. Јаблоко, Јесли ‘jeśli, jeżeli’, Јелень ‘jeleń, Крвавиј 'krwawy’, Крвистиј ob. Кровистиј 'krwisty', Личба 'liczba', Најбарзғы 'najbardziej', Овщем, овшъм 'owszem', Пазногть 'paznokieć', Пьеи 'piec', Рольник 'rolnik', Стеклиј 'wściekły', Щитель 'szczygieł', Флята 'flaga'.

W słowniku znajdujemy zapis: Глід (Глӧд) 'głód', gdzie wyraz ukraiński jest zapewne wariantem polskiego odpowiednika i, jak sam autor zauważył: „zwykle mówi się голод”. Przykład jest o tyle interesujący i intrygujący, że J. Skomorowski dodał przysłowie zawierające ten, niepotwierdzony w dostępnych pracach leksykograficznych, leksem: „Коли цвите біб, то великиј глід - а јак цвите мак, то уже не так". Także przysłowia w tej postaci nie odnajdziemy w słownikach, potwierdzony jest natomiast wariant: „Коли цвіте біб, тоді тяжко о хліб; а як мак, то не так” (Грінченко IV, 425). 
W rejestrze słownika obecne są przykłady wskazujące na mylne podanie przez autora odpowiedników polskich, np.:

- Грубарь 'grubarz' - w dialektach języka ukraińskiego rzeczownik грубар funkcjonuje w znaczeniu 'пузань' (ЕСУМ I, 603), natomiast słowniki historyczne języka polskiego poświadczają rzeczownik grubarz jedynie z semantyką: 'grabarz' (MSZP 77; SPXVI), 'człowiek zajmujący się kopaniem grobów i posługiwaniem przy grobach; robotnik zajmujący się pracami ziemnymi albo górnik' (SPXVI);

- Завалки pl. 'zawałki (słabość)' - leksem ukraiński w dialektach oznacza chorobę: 'біль у горлі з опухлими залозами (свинка), припухлі залози’ (ЕСУМ II, 216), ‘ангіна; дифтерит; запор' (ЕСУМ II, 216); zarówno w dialekcie bojkowskim, jak i huculskim odnotowano postaci: zawały, zawałky jako nazwę choroby 'skrofuloza (zołzy)' (AGB III, m. 173), 'skrofuły (choroba)' (Janów 2001: 65, 277), natomiast słowniki języka polskiego proponowanego znaczenia nie rejestrują, poświadczają formę zawałki jedynie jako 'gruczoł' nie zaś jako jednostkę chorobową (chorobę gruczołów) (MSZP 377);

- Жядниј (жяден) 'żądny (cierpiący niedostatek)', жядниј грошя o ile znaczenie podstawowe nie wzbudza wątpliwości, to umieszczone w nawiasie nie znajduje potwierdzenia (por. ECУM II, 184-185; Boryś 752; MSZP 395);

- Медведюк, Медведець ('skorpion') - w gwarach huculskich poświadczono warianty: medwedyk, medwedok, medwediuch jako nazwy dla owada 'turkucia podjadka' (Janów 2001: 125), nie zaś znacznie groźniejszego pajęczaka 5 .

Wstępna analiza ukraińskiego rejestru słownika J. Skomorowskiego wykazała również, że ukraińska leksyka zanotowana przez lwowskiego badacza nie zawsze znajduje potwierdzenie w innych pracach leksykograficznych ${ }^{6}$.

5 O. Partycki, korzystający ze słownika J. Skomorowskiego, skopiował w swoim słowniku błędne znaczenie leksemów ukraińskich: Scorpion 'медведюкъ, медведецฺь' (II, 180), a na ten właśnie, m.in., zapis zwrócił uwagę recenzent jego słownika Iwan Werchratski, zob. Skurzewska 2016: 34.

${ }^{6}$ Nie zostały w tym przypadku uwzględnione dane ze słownika O. Partyckiego z 1867 roku (Нгъмеико руский словаръ), о ile jedynie w nim odnotowano dany leksem (ponieważ autor korzystał ze słownika J. Skomorowskiego), oraz słownika J. Żelechowskiego i S. Nedilskiego (Малоруско-нїмецкий словар), ponieważ autorzy słow- 
Dlatego też nasuwa się pytanie, czy jest to leksyka bardzo ograniczona terytorialnie, czy też pojawiła się w słowniku pod wpływem języka polskiego. Oto przykłady takiego słownictwa:

(a) rzeczowniki - leksyka somatyczna:

- Болячка 'macica' - w dialektach języka ukraińskiego rzeczownik болячка zarejestrowany został jako: 'будь-яка хвороба; захворювання' w dialektach zachodniopoleskich (Аркушин I, 26), 'будь-яка хвороба внутрішніх органів' w dialektach huculskich (tutaj w wariancie болєчка (Закревська 1997: 28), ‘біль під грудьми; нарив’ па Bojkowszyźnie (Онишкевич I, 65); natomiast w dialektach języka polskiego rzeczownik bolaczka poświadczony został jako 'macica' (Warszawski I, 102, 187);

- Затъц 'zawałki (choroba nierogacizny)' - hasło zanotowane jedynie w słowniku J. Żelechowskiego jako 'Art Halskrankheit', ale bez źródła (Желеховський I, 276); na gruncie języka polskiego: zawałki w czeluściach to 'migdałki', a zawałka to 'gruczoł' (MSZP 377). Nie zostało natomiast odnotowane znaczenie podane w nawiasie, odnoszące się do choroby, a autor miał tu prawdopodobnie na myśli: zołzy pl. (końskie) wet., czyli 'ostra choroba zakaźna źrebiąt i młodych koni, objawiająca się zapaleniem błony śluzowej jamy nosowej i gardła oraz ropieniem okolicznych węzłów chłonnych' (SJP III, 1053);

- Леливо z pogardą zamiast черево - ukraiński leksem bez potwierdzenia; jedynie O. Partycki notuje zbliżony wariant: der Bauch (verächtlich) 'лелево' (I, 120);

- Лелюх, zwykle Лелюхи, pl. 'jelito, jelita' - leksem uważany jest za zapożyczenie z języka polskiego, por. pol. dial. lelochy 'баранячі нутрощі' (ЕСУМ III, 218); wyraz лелюхи notuje ЕСУМ (III, 218) 'нутрощі', ale źródłem materiału okazał się słownik J. Żelechowskiego (Желеховський II, 401) 'ts.', gdzie znajdujemy odsyłacz do słownika O. Partyckiego;

nika ukraińsko-niemieckiego w ukraińskim rejestrze uwzględnili materiał ze słownika O. Partyckiego. 
- Лядва 'lędźw' - w dialektach języka ukraińskiego zanotowano wariant лідви 'стегна' (ЕСУМ III, 258) oraz лядвія 'biodra' (Witwicki 38), 'lędźwie' (Witwicki 121);

- Потилокъ (bez tłumaczenia na język polski) - u J. Skomorowskiego rzeczownik потилокъ został zarejestrowany jako synonim wyrazu потилиия 'potylica, kark'; odnotowany jeszcze u W. Dahla (III, 942) w znaczeniu 'ударъ по затылку; затылокъ или холка у скота' (psk. twer.);

- Сустава 'staw' - J. Karłowicz (V, 265) podaje ten leksem ze Stowniczka gwary polaków litewskich (rękop.) jako 'członek, np. część palca, staw';

- Чергввниј зуб 'ząb trzonowy' - w gwarach na pograniczu łemkowsko-bojkowskim poświadczony został wariant čerevnyji (zuby) 'trzonowe zęby' (Rieger 2002: 230), O. Partycki (I, 115) proponuje natomiast forте̨ червђнний (черенний) зубъ 'der Backenzahn';

(b) przymiotniki:

- Доберъ 'dobry' - wariant morfologiczny nie został odnotowany przez inne słowniki;

- Доловатий 'dołowaty', np. поле - brak poświadczenia przymiotnika;

- Дргчний 'dorzeczny' - semantyka zanotowana przez J. Skomorowskiego nie jest potwierdzona $\mathrm{w}$ innych opracowaniach leksykograficznych; przymiotnik дрічний funkcjonuje w dialektach języka ukraińskiego, ale w znaczeniu 'люб'язний, милий; гарний, сильний' (ЕСУМ II, 131), 'учтивый, любезный, милый' (Грінченко I, 351), por. Warszawski (I, 521): dorzeczny 'rozsądny, logiczny';

- Нагуловатий 'głupkowaty' - w znaczeniu podanym przez J. Skomorowskiego notowany jest przymiotnik nahulkowatyj 'głupkowaty, narwany’ (Janów 2001: 135), 'придуркуватий’ (Онишкевич I, 464), ‘aufbrausend, heftig, jäh; einfältig; der Tölpel’ (Желеховський II, 471); wariant zbliżony do zarejestrowanego przez J. Skomorowskiego został poświadczony w dialekcie bojkowskim, ale w innym znaczeniu: нагульоватий 'запальний, гарячий' (Онишкевич I, 464);

- Поволььний, повоิльна кашя 'не густа' - ani w języku ukraińskim, ani $\mathrm{w}$ jego dialektach nie odnotowano powyższego znaczenia, por. повільний (ЕСУМ IV, 468); 
(c) czasowniki:

- Дотикнути ся чого 'dotknąć, poruszyć' - zbliżony wariant доткнутися 'anrühren, leicht berühren' został zarejestrowany w powiecie żółkiewskim (Магура 246);

w poniższych przykładach brak potwierdzenia semantyki podanej przez J. Skomorowskiego:

- Заганяти (чимъ) 'trącić czem (etwas riechen)';

- Кинути щзо 'dotknąć, poruszyć';

- Кинути ся 'dotknąć'.

Słownik ukraińsko-polski Josypa Skomorowskiego stanowi niewątpliwe wartościowy zabytek języka ukraińskiego połowy XIX wieku i wymaga bardzo szczegółowej analizy. Reprezentuje on zachodni wariant XIX-wiecznego języka ukraińskiego opartego na jego południowo-zachodnich dialektach. Nie jest wolny od nieścisłości, błędów w tłumaczeniu, zawiera leksykę, która nie znajduje potwierdzenia w słownikach historycznych, dialektalnych czy we współczesnym języku. Zbadanie zabytku umożliwiłoby ustalenie, w jakim stopniu słownictwo zaproponowane przez autora funkcjonowało w różnych warstwach językowych, a w jakim było, być może, inicjatywą samego J. Skomorowskiego. Wydaje się, że także hasła w polskim rejestrze rękopisu mogłyby stanowić materiał badawczy, ponieważ być może mamy tutaj do czynienia z regionalizmami kresowymi, o czym mógłby świadczyć zapis rzeczownika diegiedź (wobec współczesnej formy literackiej dziegieć).

\section{Bibliografia}

[AGB] Atlas gwar bojkowskich, 1980-1991, J. Rieger (red.), t. 1-7, Wrocław.

Boryś W., 2005, Stownik etymologiczny języka polskiego, Kraków: Wydawnictwo Literackie.

JANów J., 2001, Stownik huculski, Kraków: Wydaw. Naukowe DWN.

KARŁOWICZ J., 1900-1911, Stownik gwar polskich, t. 1-6, Kraków.

[MSZP] Mały stownik zaginionej polszczyzny, 2003, F. Wysocka (red.), Instytut Języka Polskiego Polskiej Akademii Nauk, Kraków: Lexis. 
RIEGER J., 1995, Słownictwo i nazewnictwo łemkowskie, Warszawa: Wydawnictwo Naukowe Semper.

Rieger J. (red.), 2002, Studia nad stownictwem gwar ukraińskich w Polsce. Eemkowszczyzna i gwary nadsańskie, Warszawa: Wydawnictwo Naukowe Semper.

[SJP] Słownik języka polskiego, 1988-1989, Warszawa: PWN.

Skurzewska A., 1999, Działalność filologiczna Omelana Partyckiego (uwagi wstępne), Між сусідами 9, s. 145-155.

Skurzewska A., 2016, Omelan Partycki i językoznawstwo preskrypcyjne w Galicji w II połowie XIX wieku, Studia Ruthenica Cracoviensia 10, Kraków: Wydawnictwo ,Scriptum”.

[Warszawski] Słownik języka polskiego, 1900-1927, J. Karłowicz, A. A. Kryński, W. Niedźwiedzki (red.), t. 1-8, Warszawa.

[Witwicki] Słownik polsko-cerkiewnosłowiańsko-ukraiński Teodora Witwickiego z połowy XIX wieku, 1997, oprac. i przyg. do druku J. Dzendzeliwski, Warszawa: Semper.

Аркушин Г., 2000, Словник західнополіських говірок, t. 1-2, Луцьк: РВВ „Вежа” Волин. держ. ун-ту ім. Лесі Українки.

Бевзенко С. П., 1960, Історична морфологія украӥнської мови. Нариси із словозміни та словотвору, Ужгород: Закарпатське обласне видавництво.

Бевзенко С. П., Грищенко А. П., ЛукіновА Т. Б. [та ін.], 1978, Icmopiя украӥнської мови. Морфологія, Київ: Наук. Думка.

БЕВзЕнко С. П., 1980, Украӥнська діалектологія, Київ: Вища школа.

ГАлАС Б., 1995, Ф. С. Шимкевич як лексикограф і украӥнське словникарство (кінець XVIII - початок XX cm.), Ужгород [б.в.].

Гринченко Б. (ред.), 1907-1909, Словарь украинского языка (Репринтне видання), т. 1-4, Киевъ.

Даль В., 1903-1909, Толковый словарь живого великорусского языка, т. 1-4, С. Петербург-Москва.

ДзЕндзЕлІвский Й., 2000, Кілька карпатсько-балканських паралелей, w: E. Wolnicz-Pawłowska, W. Szulowska (red.), Kontakty jezykowe polszczyzny na pograniczu wschodnim, Warszawa: Wydawnictwo Naukowe Semper.

[ЕСУМ] Етимологічний словник украӥнськой мови, 1982-2012, О. С. Мельничук (головн. ред.), т. 1-6, Київ: Наукова думка.

ЖЕЛЕХОвСкий Є., НЕдїЛЬский С., 1885-1886, Малоруско-нїмецкий словар, т. 1-2, Львів.

ЖовтоБРЮх М. А., РуСАНІвСьКИй В. М., СКЛЯРЕНКО В. Г., 1979, Icmopiя украӥнської мови. Фонетика, Київ: Наук. Думка.

ЗАКРЕвСьКА Я. (відП. ред.), 1997, Гуцульські говірки. Короткий словник, Львів: Інститут українознавства НАНУ. 
Коьилянський Б. В., 1960, Діалект і літературна мова, Київ: Рад. Школа.

Литературни въсти, 1862, Вечернииґ, ч. 40, Львоิвъ.

[Магура] Сборничокъ словъ и выраженій чисто-народныхъ, призначеный матеріаломъ до руского Словаря, 1863, Галичанинъ: Литературный Сборникъ, кн.1, вип. 3-4, Львовъ, s. 242-258.

МАтвіяс I., 2004, Діалектна основа вокалізму в українській літературній мові, Мовознавство 4, s. 15-24.

ОНишкевич М., 1984, Словник бойківських говірок, ч. 1-2, Київ: Наукова думка.

Стеьлій Ф. І. (упоряд.), 1989, „Русалка Дністрова”. Документи і матеріали, [online:] https://ua-kobzar.livejournal.com/340278.html [dostęp: 18.02.2020].

Сус I., 2011, Рукописний украӥнсько-польський словник „Матеріяльы до словаря русскаго" Й. Скоморовського як джерело до вивчення украӥнських говорів, [online:] https://dspace.uzhnu.edu.ua/jspui/bitstream/lib/5210/1/РУКОПИСНИЙ\%20УКРАЇНСЬКО-ПОЛЬСЬКИЙ\%20СЛОВНИК.pdf [dostęp: 19.02.2020].

Украӥнська мова. Енциклопедія, 2000, Київ: Видавництво „Українська енциклопедія" ім. М.П. Бажана.

ШевЕЛьов Ю., 2002, Історична фонологія украӥнської мови, Харків: Акта.

http://www.oda.te.gov.ua/ternopilska/ua/publication/print/18810.htm [dostęp: 25.02.2020].

[SPXVI] https://spxvi.edu.pl/indeks/haslo/53859 [dostęp: 25.02.2020].

\section{Матеріялы до руского словаря - the Ukrainian-Polish 19th century manuscript dictionary by Josyf Skomorovski}

\section{( su m mary)}

Матеріяль до руского словаря - the Ukrainian-Polish manuscript dictionary by Josyf Skomorovski - consists of 5 volumes and 1732 pages. It was probably completed in 1849. The register of the Ukrainian dictionary has 27000 entries. In the Ukrainian part, there is a lot of phonetic and lexical polonisms as well as dialectical lexical items. Some Ukrainian dictionary entries were not translated - especially in the 4th volume. Some of the Ukrainian words were presented in two orthographical variants - Skomorowski initially tried to follow the rules of phonetic orthography, but then he verified the Ukrainian part in accordance with the etimological orthography. The dictionary is not free from translation errors, it also includes some Ukrainian lexicon which has not been confirmed in other sources.

K e y w o r d s : 19th century Ukrainian lexicography; Skomorovski; the south-western dialects of Ukrainian language; dialectical lexis 